\title{
Avaliação histopatológica de 72 amostras de pulmão de bovinos com pneumonia em confinamento de terminação
}

Matheus Ferreira Serafini", Ronaldo Alves Martins, Letícia Camêlo Vespasiano, Gustavo Henrique Ferreira Abreu Moreira, Thais

Bahia de Camargos, Markus Vinicius Araújo, Felipe Pierezan, Elias Jorge Facury Filho, Antônio Último de Carvalho

Universidade Federal de Minas Gerais (UFMG), Belo Horizonte, MG, Brasil

*Autor correspondente

e-mail: mfserafini@outlook.com

\section{Resumo}

Objetivou-se identificar as principais alterações anatomohistológicas do sistema respiratório de bovinos que vieram a óbito durante o confinamento de terminação. Acompanhou-se 16.635 animais em sistema de engorda em confinamento para terminação, localizado na região norte do estado de Minas Gerais, no período de julho de 2014 a janeiro de 2015. Todos os animais que vieram a óbito $(n=134)$ foram imediatamente necropsiados, realizando-se a coleta de 3 fragmentos pulmonares/por animal (borda do lobo cranial, borda do lobo caudal e região dorsal do lobo médio), sendo esses conservados em formol 10\% tamponado para posterior análise histopatológica. Não houve interferência na adoção dos protocolos sanitários durante o experimento. Do total de animais necropsiados, 72 apresentaram alterações pulmonares sendo 45,15\% Broncopneumonia (30 amostras), 21,54\% Pneumonia intersticial (14 amostras), 13,85\% Pneumonia bronco intersticial (9 amostras). 0 restante das amostras dividiu-se em menor expressão entre Pleurite Fibrinopurulenta, Pneumonia necropurulenta, Congestão pulmonar, Pleurite Fibrinosa e Pleuropneumonia. As lesões de broncopneumonia são similares àquelas causadas por M. haemolytica, P. multocida e H. somni, com grande quantidade de infiltrado inflamatório neutrofílico, degeneração celular e presença de bactérias nos sítios de lesão. A pneumonia intersticial, com grande acúmulo de material eosinofílico amorfo na luz alveolar, edema, lesão endotelial, células gigantes multinucleadas e proliferação intensa de pneumócitos tipo II com espessamento dos septos alveolares, sugere uma causa viral ou tóxica como BRSV e PI-3 ou amônia e 3-metilindolamina. Além disso, há associação entre broncopneumonia e pneumonia intersticial, sugerindo que um tipo de pneumonia pode ser predisponente para outra. As mortes ocorreram de forma aguda e rápida e, contrariando a literatura, foram mais frequentes em animais próximos ao peso de abate sem manifestação clínica da doença respiratória. Devido à dificuldade de identificação de bovinos com alterações respiratórias no rebanho e, muitas vezes, da intensidade do quadro respiratório instalado, a 
avaliação post mortem se faz uma ferramenta eficaz para avaliar a gravidade das doenças respiratórias, fornecendo subsídios para implementação e monitoramento de medidas de controle. A histopatologia também foi essencial para a definição de lesões graves que não puderam ser diagnosticadas durante o exame clínico e para a avaliação macroscópica dos animais. As broncopneumonias foram as alterações mais encontradas nos animais necropsiados no presente trabalho. 